\title{
CRISES, LONG WAVES, AND WORLD-SYSTEM ANALYSIS
}

\author{
Andrea Komlosy \\ University of Vienna
}

\begin{abstract}
The article introduces the concept of long waves or business cycles. It argues that by framing business cycles in a world-system perspective, its initially Western centric character could be overcome and could be used for analyzing the polarizing tendencies of global capitalism as an uneven and combined economic system, constantly producing and reproducing cores and peripheries. Moreover, world-system scholars interconnected business cycles with hegemonic cycles, characterized by a primus inter pares among the dominant core powers. While the hegemon is acquiring an accepted leading position based on economic, military and cultural power, cyclical change is undermining this position, giving way for competing successors. Based on historical explorations of British and US hegemony, the article discusses the prospects of a hegemonic succession after the decline of the United States. It analyzes whether such a hegemonic change will take place in the framework of the capitalist world system, eventually leading to a period of presumably Chinese hegemony, or whether the current global turmoil will rather open a period of chaos, putting an end to the cyclical renewal of global capitalism, as we experienced during the last 500 years.
\end{abstract}

Keywords: long waves, Kondratieff cycles, business cycles, hegemonic change, core and periphery, capitalist world-system, world-system analysis, crisis, crisisdiscourses.

The global economic crisis of 2008-2009 apparently seems to be overcome. The world economy did not regain stability, however. Starting point for my deliberations is the current phase of world economic turmoil. It provides a lot of data about the catastrophic character of crises, which spread from the economic sphere to social, political and military domains. It also allows analysing the crisis as a chance for a transformation towards a more socially just world economy. To sound out these chances a comparison with previous great crises - 1973/74, 1929, and 1873 - may appear helpful.

The concept called long waves, or cycles, of economic activity is suitable as a method for historical framing. Many historians have discredited it in recent years for being too mechanistic or economistic. Some economists, on the other hand, regard this concept as a too complex to serve as a foundation for forecasting due to its emphasis on historical change. In addition, it focuses on developed industrial states and ignores the perspective of the peripheries. But long waves are still important today as mainstream economists have failed to assess the recent crisis and to develop a broader, multilayered approach to crises as such. The global character of crises can only be assessed with due consideration of the shifts and different ways in which specific world regions are affected by a crisis and the restructuring measures resulting from it. From the per-

Journal of Globalization Studies, Vol. 10 No. 2, November $201955-76$ DOI: $10.30884 / j o g s / 2019.02 .05$ 
spective of a world-system analysis long waves are used in order to put geographical inequality on a regional, national and global scale as well as their dynamization through crisis in relation to the sequential pattern of economic cycles. In this regard, historical comparisons are used to discuss whether economic crises are of a system-stabilizing or system-overcoming nature. Core formation, peripheralization, competition and hegemonic shifts within the world economy can contribute towards a more complex assessment of crises. Moreover, I will also address crisis-discourses and perceptions of crisis which do not always concur with ostensible economic parameters.

\section{Long Waves}

Long waves are a method of classifying the cyclical progression of the capitalist economy by using models of short-, medium-, and long-term movements of waves (up- and downturns, expansions and contractions, growth and shrinking) for measuring. In doing so the different explanations from different ideological worldviews - cycles of innovation (Kondratieff 1993 [1925]: 24-83; Schumpeter 1939), capital accumulation (Karl Marx and Ernest Mandel 1980) or the political economic regime (Bornschier and Lengyel 1992) - show great compatibility. In contrast to shorter investment- and business cycles, long waves basically consist of an upswing which usually lasts about 20-25 years so far (also called Kondratieff-A-phase) and is characterized by widening production and demand with growing prices and growing rates of profits. These are followed by a downturn of equally long duration (called Kondratieff-B-phase) initiated by a crisis of profit and overproduction. It provides an impetus to efforts to achieve lower costs and rationalization, thus creating the conditions for a new upswing. This phase is characterized by sharper competition between companies, many of which cannot hope to survive. The fall in prices and profits causes a flight into financial markets, opening a new role for business locations in the periphery. By taking a closer look, a long wave, i.e., a cycle, can be separated into four phases: prosperity, recession, depression, and recovery.

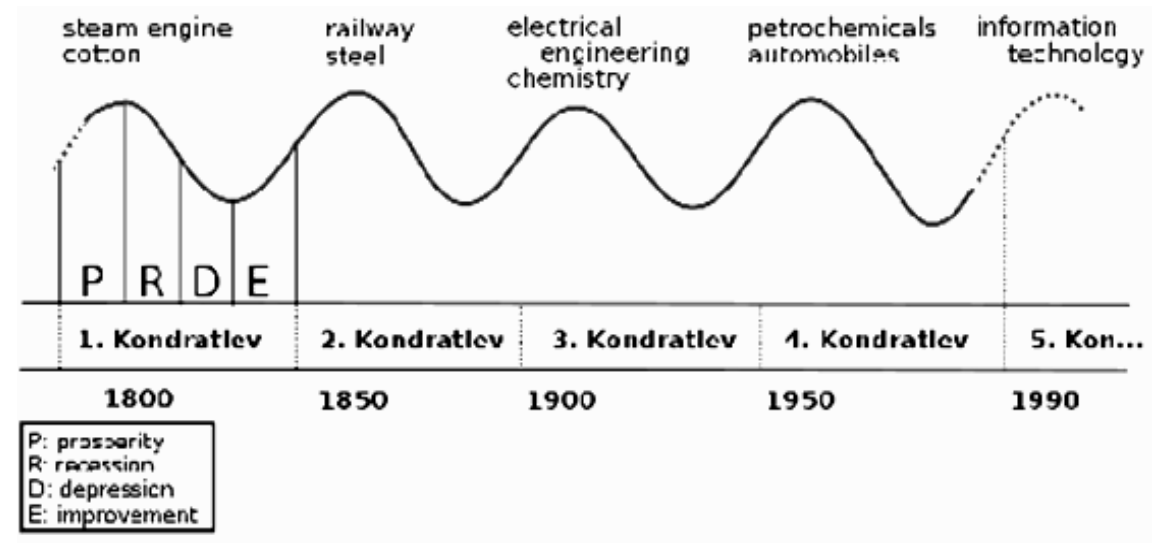

Kondratieff cycles

Fig. 1. The phases of the cycle

Source: URL: http://de.wikipedia.org/wiki/Kondratjew-Zyklus. 
Since long waves have been observed but not reliably proven or justified they are considered to be economistic, mechanistic and too schematic to do justice to the complexities of the real world. This is true. They cannot represent reality. They give an impression of repetition although the root causes for each cycle are different. They are vague, open for interpretation and do not allow making predictions. However, this does not distinguish them from other construction models usually used in social sciences. Here they are used for structuring and comparing complex developments. The aim of this exercise is to study the great historical world economic crises. Can cyclical models lead to a deeper understanding of crises and eventually even contribute to predicting future developments?

\section{Historical Cycles}

The cycles or long waves described by and named after Nikolai Kondratieff in 1925 derive from movements of production, prices and wages within the industrial sector of the respectively leading industrial countries. The first Kondratieff cycle began with the first high phase of the Industrial revolution carried by the mechanization of the textile industry in the UK, which began around 1790 . The leading industrial sectors during the following A-phases were the railway industry (the $2^{\text {nd }}$ Kondratieff-cycle, 1850ff.), steel, electrical, chemical and food industries (the $3^{\text {rd }}$ Kondratieff-cycle, 1896ff.) as well as car manufacturing (the $4^{\text {th }}$ Kondratieff-cycle, 1945ff.). There exists substantial consensus about the A-phase of the $4^{\text {th }}$ Kondratieff-cycle being fed by reconstruction after World War II, leading to unforeseen potentials in demand for consumer goods being mobilized and affecting several surrounding sectors. At the turn of the $1960 \mathrm{~s}$ - the 1970s the rates of profits sank. This, together with the rise in oil prices, culminated in the world economic crisis of 1973/74.

Long waves according to Kondratieff

Table 1

\begin{tabular}{|l|c|}
\hline \multicolumn{1}{|c|}{ Kondratieff A-Phase } & Kondratieff B-Phase \\
\hline $\begin{array}{l}1790-1820 \\
\text { Textile industry }\end{array}$ & $1820-1850$ \\
\hline $\begin{array}{l}1850-1873 \\
\text { Railways, steel }\end{array}$ & $1873-1896$ \\
\hline $\begin{array}{l}1896-1914 \\
\text { Electrical, chemical and food processing industries }\end{array}$ & $1914-1945$ \\
\hline $\begin{array}{l}1945-1973 \\
\text { Petrochemical industries, car manufacturing }\end{array}$ & $1973-1990 ?$ \\
\hline
\end{tabular}

A phase of prosperity where a new lead-product, source of energy and propulsion technology (hydro power $>$ steam power $>$ electrical engine $>$ conveyor belt) was met by growing demand carried within itself the first germs of crisis (recession) in form of exhaustion of profit margins, the strengthening of competition and market saturation. Depression duly follows. Phases of depression are marked not only by downturns and collapse but also by a search for renewal: rationalisation in existing industries, product innovation in new sectors, development of new technologies, raw materials or their substitution, lowering of labour costs through scientific management (factory system, 
Taylorism, Fordism) in the centre and the acquisition of new sources of raw materials and extended workshops in the periphery of the world economy. During the transition from depression (B-phase) to recovery (A-phase) political-economic framework conditions in individual states also change, meaning the legal, institutional embedding and safeguarding of the newly adopted accumulation-strategy. If needed, production and demand will be stimulated by military means - in the full knowledge that devastation caused by war could form the basis for the next upswing. The orchestration on state level is accompanied by attempts for an internationally coordinated regulation from which established producers expect protection of their advantages, whilst developing and emerging nations expect help in their attempts to catch up in their development.

Actually, looking at the sequence of prosperity and recession or depression and recovery before and after the peak or the low level, as Schumpeter did in his Business Cycles (1993), provide a more applicable subcategorization than the mere division into A-upswing and B-downturn phases.

When comparing the world economic crisis of 1873 and 1973/74, similar patterns can be found despite all the differences between them. ${ }^{1} 1873$ marks the turn from the years of rapid industrial expansion carried by the railway boom between 1867 and 1873 to a long-term phase of stagnation. This period was marked by numerous innovations led by automation of production, the spreading of industrialization towards chemical processes and food processing as well as the development of electrical industries which in the end led to the turn from central transmission belts to the development of single motor drives. This started a modernization of industrial facilities during the phase of depression. In order to survive the competitive climate rural regions in the periphery were developed for industrial use due to lower land prices and labour costs. Locations outside Europe except for the United States, Japan as well as smaller enclaves in British India and Mexico did not experience factory-style industrialization: their role was to deliver raw materials and food as well as to provide markets for ready-made goods manufactured in the industrializing nations. Colonies and economically dependent nations were bound to European colonial powers by way of 'classical imperialism' in order to safeguard economic and strategic resources against competing interests. In the industrial countries factory labour expanded massively. Factories were organized according to Taylorist principles. Daily life and people's lives changed significantly due to wage labour, urbanization, state regulation, mobility and commodification. These adjustments carried the second phase of industrial expansion from 1896-1912.

The global economic crisis of 1929/31 is more complex than the crisis of 1873 and 1973 , as the era between the two world wars was strongly conditioned by the dynamics caused by political events (Galbraith 2009; Roth 2009: 285ff; Wolf 2009: 182-185). Usual periodizations describe both world wars including the phase between the wars as one long-term period of crisis. However, the First World War can also be seen as the last effort to prolong the A-phase of the second period of expansion by increasing the demand for war materials and thus breathing life into the economy. For the Axis powers this renewal ended in failure followed by the break-up of major empires, new states being founded and, in case of Russia, one social revolution leading to the foundation of the USSR. 
From the point of view of the majority of the population, military conscription and service, battles of production and serving at the home front cannot be equated with the term 'upswing' anyway. It was crisis per se, even though (most) sides raised it onto a patriotic pedestal. The war economy, under the mantle of military considerations, opened up new opportunities to introduce rigid regimes of management and control that were also useful in times of peace. The followers of socialism even interpreted farreaching state power to access management, labour and distribution as an example to follow for the governance of a planned economy. Rebuilding after World War I did not have lasting regenerating effects due to the disintegration of the major powers, border conflicts, population transfers as well as conflicts about the constitutional arrangements for the successor states. It was a continuance of economic depression. However, the post war order established by peace treaties offered better starting conditions to the victorious Entente-nations and their allied states than to the losers. Whilst the Soviet Union concentrated on socialist transformation, the United States of America which had not suffered any damage during the war is able to increase their economic superiority within the world economy against the old colonial empires. Reconstruction credit was bound to restrictive budgetary policies. Monetarist economic policies strangled any impulse for growth.

The collapse of the New York Stock Exchange on the $24^{\text {th }}$ of October, 1929 and the resulting feedback effects triggered the world economic crisis. International Dollar loans were withdrawn, companies and banks collapsed as did prices for raw materials. A massive decline in production and foreign trade followed. Deflationary economic policies strengthened the decline further. An international coordination to solve the crisis failed. As a result, the world economy broke down into trade- and currency-blocks of the major powers who tightly bound up their colonies and trading partners to themselves. Lacking colonies of its own, Germany set about building a large-scale area under German domination in Eastern Europe. Emerging nations like Brazil, Mexico or Turkey were able to gain some breathing space due to the turbulences in the cores. This made it easier for these countries to begin with catching up on their own industrialization. Because of its isolation the Soviet Union was also barely touched by the crisis and concentrated on developing its industries. Whilst developing nations with ambitions for an independent economic policy were therefore able to use the crisis for strengthening their own national economies, the core nations were hit by a paralysis, which they carried into their colonies and backyards as well.

Neither the New Deal in the USA nor work creation programmes in Nazi Germany was able to bring an end to depression. Economic recovery came only after the end of the Second World War. Many restructuring measures of the war economy led to modernizations, just like after the First World War. These were retained during the recovery. But violence, suffering and destruction are the main reasons for the beginning of the next A-phase usually being dated towards the end of the war.

The crisis of 1973/74 did not trigger a recession comparable to those of 1873, 1929 or even 2008. GDP growth went down but did not drop to a minus (Wolf 2009: 23). It nevertheless marks a turning point where the Fordist welfare state of the reconstruction years is being replaced. The answers to the crisis of 1973/74 marked a process of re-globalization and thus reconnected with the phase of classic imperialism after the 
world economic crisis of 1873, when realization blockades in the cores were overturned by product- and process innovations as well as the valorization of internal and external peripheries by capital exports, raw material extraction, industrial relocation and credit expansion.

\section{Long Waves and World-System Analysis}

At its core debating long waves is a narrative viewing the world economy from a eurocentrist western perspective. This also includes the USA, which has risen to become a leading industrial country during the second half of the $19^{\text {th }}$ century. The crucial factor for assessing the A- and B-phases of recession, depression, renewal and prosperity are the western industrial countries. At the same time cycle theory claims to have universal validity characterizing the entire world economy across national borders. For the colonial age this means that colonies are viewed as being part of their mother countries. This also applies to sovereign states and empires in so far as these became dependent on major European powers or the USA. Whether different economic cycles have a lifting or stunting effect on the development of colonies and peripheries of the world economy is not a matter of the debate as long as these regions do not succeed in articulating themselves as actors with independent interests and perspectives. They were able to do this by demanding greater inner autonomy within the empires themselves. Internationally, the aspiration for their own development perspective was formulated by way of independence. They raised a claim for becoming cores themselves through catch-up development, thus being able to shape the cyclical movements of capital accumulation with their own lead products and lead processes.

World-system analysis on the other hand understands the world economy as an interdependent web of relationships, which allows regions with good starting conditions to enjoy advantages at the cost of regions that due to relative economic and political weaknesses have to allow development, valorization and appropriation of values by others who are stronger than them. Thus, the formation of centres (or cores), peripheries as well as semi-peripheries is an expression of the unequal integration of regions into the supraregional division of labour. Thus, the concept of 'system' starts with assessing the function of regions within a supraregional, state-crossing division of labour. Economic integration is therefore exceeding the territoriality of sovereign states. But because of their varying political strength and constitution states also contribute to the regional differentiation of the world economy (Wallerstein 1983).

The historical moment usually ${ }^{2}$ used to pinpoint the beginning of the development of the unequal supra-regional division of labour within the capitalist world system is the western European expansion into north-eastern Europe and into the Americas, leading to those regions becoming world economic peripheries supporting capital accumulation in the centres (or cores) through delivery of cheap food and raw materials. Initially only based in western-Europe, north-eastern Europe and the Americas during the sixteenth century, capitalism centered in north-western Europe began expanding successively during the seventeenth century until in the nineteenth century it had subjugated all world regions to its mechanisms of expansion, development and functional inclusion into an unequal division of labour. The systematic transfer of values from the peripheries to the centres of the world economies is being explained with unequal opportunities 
for value creation and appropriation. Centres, peripheries as well as rising and declining semi-peripheries are explained as an expression of historical power relations. When inner and outer framing conditions change, developments of core formation and peripheralization are also subject to change: this applies to the foundations spatial polarization is based on as well as the geographic placement of centres, peripheries and semiperipheries.

Leading authors committed to world system analysis have been integrating the concept of long waves as a building block into their models since the 1970s. ${ }^{3}$

The model of cycles greatly changed due to its connection to a world-system context. Two main aspects may illustrate the specific contribution of a world-system approach for understanding cyclical movements of capital accumulation.

First, upswings and downturns do not mean the same for cores and peripheries within a division of labour characterized by small- and large-scale inequality and dependency. The turn from depression to new prosperity must not only be linked to sectoral and technological renewal. As the turn goes hand in hand with a stronger integration of peripheries into the world system - which contributes to the regeneration for the whole system - the cycle also has consequences for the geographic position of cores and peripheries and therefore the spatial structure of the world system. It can lead to the transformation of peripheries into semi-peripheries or centres, to the decline of former centres or semi-peripheries and also to a new gestation of peripheralization. For example, a periphery based on raw materials can be transformed into one functioning as a region delivering nature or recreation for tourism, as an outlet for waste deposits, or as an extended workbench. Expansion as part of an upswing means rising demand for raw materials in the centres - for raw-material peripheries this means intensifying exploitation, valorization and penetration primarily aimed at delivering resources to the centre. This also demands investment in traffic infrastructure, storage facilities as well as facilities for refining and primary processing of raw materials. Peripheries become attractive locations for manufacturing industries only when process innovation in the core has come to an end and standardized aspects of production can be carried out by less qualified workers. The relocation of industrial production into the periphery is concentrated on those branches and sectors of the economy that have already lost their lead function in the old industrial countries. The shift into the peripheries often only affects work intensive steps of production whilst keeping the leading and value creating company functions in the old industrial centres, meaning that growth through catch-up industrialization does not necessarily lead to development. The new international division of labour thus leads to new forms of dependency of the periphery on the centre. In the centres, the growth dynamic during the next cycle shifts to a new lead sector. During this restructuring new regions can consolidate themselves as industrial centres while older industrial regions are forced to the fringes, however.

As long as the shift into the periphery is being driven from the centres, the former will depend on the latter. But catch up-industrialization can also trigger impulses leading not only to the development of new centres within the periphery but also to the rise of a periphery to becoming a core of the world economy. Successful rise depends on the economic cycle, changes in the steering of the global commodity chain, the legal international framework and the economic-political decisions being taken on the local or 
national level, but also on a given country's or region's ability to assert its upgrading against competing rivals. Size, resources, industrial tradition, available qualifications, capital and the political and institutional framework are crucial for whether foreign direct investment leads to an industrialization based on dependency or to the transformation into a regional industrial centre (Komlosy 2012a: 11-42).

Secondly, focusing the spatial impact of long waves on the geography of cores and peripheries allows for embedding economic cycles into so-called hegemonic cycles (Wallerstein 2011; Arrighi 1994; Frank 1998; Taylor 1996). These are characterized by a hegemonic power dominating the world economy. A hegemonic power is understood to be a state wielding a leading role in the world economy and the military field, controlling the world finance sector and whose values and way of life are considered to be the world's leading culture. It also forms part of hegemonic status that its power and leadership are accepted by allies, dependents, rivals and enemies. Such a situation can only exist when certain conditions are met. Historically, multi-polar phases in which different centres compete for hegemony are much more common than unipolar phases with only one dominant core. Empirical observations show hegemonic cycles with duration of around 100 years. Hegemonic cycles are characterized by the rise, victory, maturity and decline of a hegemonic power. A mostly unchallenged hegemony exists only during the phase of maturity. All other phases of the cycle are characterized by fierce competition to achieve supremacy against previous powers and rivals, and defensive battles against possible successor powers during the phase of decline.

Overview 1. The geographical expansion of the capitalist world system.

The $12^{\text {th }}$ century: Beginnings in Venice, Islamic Mediterranean;

The $13^{\text {th }}-15^{\text {th }}$ century: Expansion to Upper Italy, Upper Germany, and Flanders;

The $16^{\text {th }}$ century: Global rise from Northwestern Europe (Core) to southern and central Europe (SP), Northeastern/eastern Europe (P), American colonies (P);

The $18^{\text {th }}$ century: Incorporation of the Ottoman Empire, Russian Empire, western Africa, the Indian subcontinent, eastern and southeastern Asia $(\mathrm{P})$

The $19^{\text {th }}$ century: Incorporation of Africa, Oceania and further parts of Asia $(\mathrm{P})$.

The prevalent historical narrative of world-system theory as substantially shaped by the narrative of Immanuel Wallerstein $(2001,1998)$ views the seventeenth century Netherlands as the first hegemonic power. It was able to assert itself against upper Italy and upper Germany who had been the economic backbone of Europe during the fifteenth and sixteenth centuries. Their dominating position was based on a system of cities that had more or less leading roles depending on the situation, but did not exercise hegemony. A hegemon had only been able to arise when economic expansion was combined with state interests to support, promote and protect business and trade. When the European core regions had shifted from the Mediterranean to the north Atlantic during the seventeenth century, the old centres declined and turned into semi-peripheries. The General States of the Netherlands developed into a new economic core. After a series of wars involving the Netherlands, England and France, the United Kingdom became the hegemonic power of the nineteenth century - in competition with France during its ascendance, challenged by the USA and the German Empire during the phase of decline. After two world wars the United States came out of the German-American con- 
flict as the victorious power. It went on to dominate the 'American century' as a global hegemon between the mature years of 1945 and 1973. The USA had to tolerate a counter hegemon represented by the Soviet Union, which did not fulfil a leading economic function but was able to achieve hegemonic status in its sphere of influence due to its primacy of the political and the military power flowing from that. Both hegemon and counter hegemon went into decline with the onset of world economic crisis in 1973/74. Whilst the 'Eastern bloc' with its Council for Mutual Economic Assistance (CMEA, also referred as COMECON) and the Warsaw Pact collapsed in 1991, the decline of the US hegemony was characterized by the attempts to compensate for and delay the loss of hegemonic power through militarization, expansion of alliances and the use of alliance commitments as well as the use of the US Dollar as the global reserve currency.

Table 2

Long waves and hegemonic cycles, 1790-1990

\begin{tabular}{|l|l|c|l|}
\hline \multicolumn{1}{|c|}{ Hegemon } & \multicolumn{1}{|c|}{ Kondratieff A-Phase } & Kondratieff B-Phase & \multicolumn{1}{|c|}{ Hegemon } \\
\hline UK-upswing & $\begin{array}{l}1790-1825 \\
\text { Textile industry }\end{array}$ & $1820-1850$ & UK-victory \\
\hline UK-maturity & $\begin{array}{l}1850-1873 \\
\text { Railways, steel industry }\end{array}$ & $1873-1896$ & UK-downturn \\
\hline US-upswing & $\begin{array}{l}1896-1914 \\
\text { Electrical-, chemical-, } \\
\text { and food processing } \\
\text { industries }\end{array}$ & $\begin{array}{l}1914-1945 \\
\text { 1945-1973 } \\
\text { Petrochemical industry, } \\
\text { car manufacturing }\end{array}$ & US-victory \\
\hline US-maturity & & US-downturn \\
\hline
\end{tabular}

Britain's ascent happened (in competition with France) during the A-phase of the $1^{\text {st }}$ Kondratieff-cycle (1790-1825), its victory as a hegemon was achieved during the following B-phase (1825-1850); during the A-phase of the second Kondratieff-cycle (1850-1873) British hegemony reached maturity. It was challenged by the USA (and Germany) during decline (1873-1896). The ascent of the USA began during the long phase of crisis between the two world wars (1919-1940). During the second half of the $20^{\text {th }}$ century it underwent victory, maturity and decline.

To view history as ascension and decline of major powers has long been a tradition in historical and political science. A world-system approach is able to fruitfully use the ground between the poles of geographically confined state policy on one side and economic action space - which is overcoming the borders between states - on the other. Hegemony is therefore not primarily founded in the political strength of one state but rather in the capability to control the transnational flow of goods, capital and labour in such a way that profit gained from such global commodity chains is mainly realized in one's own sphere of rule. Thus hegemonic cycles are based on economic long waves. Questions of political power cannot be understood without relating economic foundation as well as world economic constellations. In contrast to a purely economic determination of a business cycle, as conceived of in the models of Kondratieff and others, hegemonic 
cycles are rooted in political events. Not only do war, arms expenditure, conquest and the formation of alliances play a central role in periodizing ascent, victory, maturity and decline of hegemonic powers. They also interact with prosperity, recession, depression and recovery within the economic cycle.

\section{Crisis within the System - Crisis of the System?}

In the following pages long waves, the new formation of centres and peripheries and hegemonic change will form the base for discussing crises within the world system. Is capitalism a cyclical sequence of A- and B-phases following each other, where crisis is an immanent systemic mechanism to overcome out-dated arrangements of production and division of labour whilst developing renewed organisational, technological and geographical arrangements as a base for a new expansive phase? The concept of economic long waves suggests such an interpretation. In its bourgeois-liberal incarnation "creative destruction' (Schumpeter 1939) prepares the terrain for a new wave of innovations. Political system change is not needed. From this point of view, phases of authoritarian suppression of the parliament aiming at breaking people's resistance against the social consequences of 'creative destruction' are considered to be anomalies. However, they can also be considered to be immanent to the system. From this perspective, crisis represents a periodically reappearing chance provided by the system to adapt structures and habits of economic life to the newest level of technology and management. Therefore, the bourgeois-liberal discourse does not dramatize crisis. On the contrary, crisis is - more or less openly - seen as a welcome occasion for pushing back gains won by the workers movement or distribution mechanisms granted by governments during the A-phase, such as taxes, wage increase, workers' rights and social security. On the other hand, the capital side demands from the state to privatize, liberalize and unblock stagnant capital accumulation (see, e.g., Streissler and Tichy 2012). The key question in this case is about who has to pay the price for the crisis: Is it manufacturing companies or banks, large and small businesses, entrepreneurs or working people, the permanent workforce or those with precarious jobs with their various specific interests? It is in the interest of the strongest capitalist groups to prevent public discussions of budgetary reallocations from social benefits to subsidies for banks and businesses. They are to be presented as inherent necessities for saving the system instead.

In the world-system approach, historical capitalism is viewed as a system of expansive, continuously reproducing capital accumulation leading to regional inequality. Although it is understood as a critical analysis, it is essentially based on the interpretation of crisis as a moment of chance and renewal. The concept of crisis differs from the liberal approach. Instead of viewing crisis as a chance within the adaptation mode of the system towards the demands of unfettered capital accumulation, it can also be regarded as a chance towards overcoming the system itself. Following from Karl Marx, the nineteenth-century socialist theoreticians founded their visions of a socialist transformation on a theory of crisis that combined social, economic and political aspects. There was a conviction that the crisis within the system would turn into a crisis of the system, thus allowing for a new beginning in which the productive forces matured under capitalism would be put under the control of a new collectivized and therefore more rational mode of production. This new mode of production of the future would have no need for cyclic cri- 
ses. The insight about the coming final crisis of capitalism united the nineteenth-century socialists from different theoretical and tactical backgrounds. But when the twentiethcentury capitalism showed a remarkable capability of re-emergence from crises, with Soviet-type state socialism not being able to do anything about this, the forecasts about the final crisis mostly faded away. Socialists either acted within the framework of the system alternative of the state socialist planned economy or concentrated on strengthening the social elements of the market economy.

The 'golden years' of prosperity after WWII relegated the overturning of capitalism towards an unreachable future. Left-wing world-system scholars open to the formation of a socialist society were no exception to this. They did define capitalism as a historical system, which, if it had a beginning, could also conceivably come to an end (Wallerstein 1983). But historic-empirical analysis focused on cyclic renewal and its related changes in the constellation of core formation, peripheralization and hegemonic change. The insight that system change could come on the practical-political agenda of the day only appeared around the turn of the millennium. On the one hand, the collapse of state socialism demonstrated that system change was possible. On the other hand, the opening of Eastern Europe that had helped to overcome the crisis in the West caused even bigger problems. Immanuel Wallerstein opened a new debate with his book Utopistics: Or Historical Choices of the $21^{\text {st }}$ Century (Wallerstein 1998). He thought it was possible and provided arguments explaining why cyclic renewal and reformation could not really get off the ground following the world economic crisis of 1973/74. In his estimation renewal was not able to come up against resistance immanent within the system itself. First, it was not possible to curb the profit squeeze by shifting production and externalizing the costs. Available potentials of renewal in the form of raw materials and labour reserves ready for access without having to care about reproduction costs showed signs of exhaustion. This, secondly, led to rising costs causing a crisis of capital accumulation. According to Wallerstein, the third factor is a crisis of legitimation of the state. Due to shrinking income and rising expenses states are increasingly less able to compensate for dissatisfaction and to provide national identity. Competing offers of regional, ethnic and religious nature lead to an erosion of social cohesion and to an opening of new rifts within society.

Today more than ever, Wallerstein $(2011,2013)$ is of the opinion that historical capitalism is in its phase of final crisis, though without providing forecasts about the end of this crisis. In contrast, other social scientists do not interpret social crisis phenomena as an expression of breakdown and transformation but rather as an adaptation immanent within the system (e.g., Frank 1998). A debate flared up reaching far beyond the field of world-system analysis, also involving the question of hegemonic change in the world system. Let us play out the arguments using the world economic crisis of 1973/74.

\section{Business as Usual: Crisis as a Mechanism Immanent within the System}

Viewed from a hegemonic perspective, counter-strategies and the overcoming of crisis can be regarded as reforms on the one hand, or mechanisms of adaptation and reordering, on the other. The answers to the world economic crisis of 1973/74 offered both. Whilst reform measures were associated with social mobility, advancement and a spirit of optimism as well as inclusion, measures of adaptation stood for rationaliza- 
tion, externalization and outsourcing, leading to a regional and global rise in social inequality. 1973/74 stands for the beginning of a B-phase. Reforming measures were supposed to lead to the development of new qualifications needed to combat the crisis and the overcoming of social hierarchies in order to remove barriers to social, professional and social mobility as well as the mental readiness for change. In many ways these reform measures related to the anti-authoritarian spirit that had emerged with the social movements during and after 1968 (Roth 2009: 148ff). The social dynamic triggered by this led to the B-phase being experienced as an upswing by many inside the cores of the world economy. This shows that individual and collective perception of crisis does not necessarily correspond with the cyclical movement of economic indicators.

Although the 1973/74 world economic crisis did not trigger recession, shrinking profits, rising wages and social costs as well as sharpening international competition slowed down the tractive forces of the leading sectors which had been carrying the Fordist model of production and consumption in the centres of the world economy so far. In reaction, rationalization and re-structuring of locations on a world scale should allow to overcome declining profits. Many owners of capital preferred financialization over productive investment, however. This tendency is characteristic for the turn from an A- to a B-phase. This, as well as the money flowing from oil-producing countries into the financial system of course, created the credit facilities enabling the new international division of labour (Fröbel, Heinrichs, and Kreye 1977). Labour-intensive production was transferred to developing countries of the south, but also to Eastern Europe, where then still socialist governments hoped for a way out of their innovationblockades in this way. The globalization of commodity chains allowed a significant lowering of production costs for industrial mass goods. The most value adding departments of research, development and logistics requiring a highly educated workforce remained in the old industrial countries whilst the Newly Industrializing Countries took over low wage manufacturing. A turn towards new lead sectors and processes happened in the metropolises. New technologies and increased flexibility of work as well as the moving of labour intensive production to low wage industrial locations played a part in the crisis being viewed as a period of departure in the old cores. In addition, the neoliberal order created to re-establish profitable capital valorization was initially overlapped by anti-cyclic programmes designed to delay adaptation to the changed necessities of capital valorization. Therefore the economic-political turn lagged behind the economic cycle. But anti-cyclic policies were only able to delay or keep away the results of adaptation from the core sections of the working class by externalizing the costs. The price to be paid for the relatively mild manifestation of the depression during the 1970s and 1980s was growing inequality. Whilst the permanent workforce was shrinking because of relocation and digitalization, precarization, fluctuation and flexibilization of labour relations began to reach the old industrial countries as well.

From the point of view of capital looking for valorization it was a successful renewal. The new international division of labour combined with digitalization of production and the globalization of commodity chains caused a massive extension of crossborder economic activity. This can be read from increased international trade, direct investment, debt and financial transactions. Multinational corporations carried interna- 
tionalization of production. The governments of emerging countries hoped to get a step up the ladder of catch-up industrialization through direct foreign investment.

Along with the transformation of the world economy there came a dismantling of work-, tax-, and trade-regulations as well as of legal requirements and restrictions for investors. The competition between states for high ranking and profitable investment caused a race to the bottom, giving the opportunity to multinational corporations to play out individual suppliers or states against each other, or to replace them if needed.

The successful transformation eventually also put into question the 'achievements' gained by wageworkers in the old industrial countries. Flexibilization, precarization and commodification of social security began to supersede the old paternalistic Fordist welfare state model. Labour and trade union representatives tried to rescue what they believed they could save. This only succeeded if the right of access to social security was limited to a privileged core of the labour force. But the number of workers which did not belong to the core workers began to grow as early as during the 1980s. Whilst labour migrants from cheap wage countries were seen as competition on the labour market, those colleagues working far away in sub-companies, world market factories and free production zones remained mostly invisible. The metropolitan working class experienced them solely by way of cheap goods, which were soon regarded to be consumerist 'achievements'. This united them with the principles of global commodity chains.

Let us put this argument in relation to the cycle. The reforms and adaptation measures during the B-phase after 1973/74 prepared the ground for a new upswing. The fifth long Kondratieff wave went through its A-phase from 1990 until 2008 and tipped into recession with the world economic crisis beginning in the year 2008 which we are still experiencing today despite short-term recoveries and their different regional and sectoral developments. The prosperity of the new cycle was based on a new era of rapid economic expansion made manifest in the boom of telecommunication, the IT-sector and biotechnology. These were knowledge-based sectors gaining their material foundation for chips, microprocessors, computers, communication devices and everything needed for this hardware from the world market factories of the global south (which now include the former socialist countries in Eastern Europe). Compared to global restructuring in the previous $4^{\text {th }}$ Kondratieff B-phase, ownership command and logistics within the global good chains experienced restructuring. In this period globalization of industrial locations took place under the aegis of multinational companies who multiplied the spectrum of employment types, costs and regulatory laws via their affiliates, sub-companies and contracts with subcontractors, whilst during the fifth Kondratieffcycle more and more producer companies were replaced by so-called 'global buyers'. These 'buyers' consist of wholesalers, retail chains and brand owners who select, determine and combine locations along the commodity chain from the point of view of demand and not of production (Gereffi 1994). This means that metropolitan centres that had retained strategic sections of valorization during the first phase of globalization of commodity chains seized to be irreplaceable. The command over global commodity chains began to partially shift towards regional centres like Sao Paolo, Mexico City, Hong Kong or Shanghai. As global cities, they were able to open up the value chain for local as well as transnational elites. The possibility to transform catch-up industrialization by contract manufacturing into regional development and the rise to a new capital- 
ist class spread a mood of and a hope for departure in the Newly Industrializing Countries. This, of course, only concerned the winners of these developments, which, wherever they took place, gave way to deep social and regional polarization. In Eastern Europe, China and Vietnam this took place within the context of political economic system change.

There was a mixed appreciation of the upswing in the old cores, now better called former rather than old industrial countries due to global shifts in many aspects. As shining as the new post-industrial industries are, as attractive the new flexibility is, as adventurous the new careers seem to be, as far as digitalization and commodification of communication has spread into the living worlds of the broad masses so that no one wants to miss - the new upswing went together with polarization and a split in society creating winners and losers. Those belonging to the group of the losers had to accept in part huge social cuts interpreted by those affected as 'crisis'. From the perspective of systemic stability, these hardships are accompanying the phenomena, signs of and downright preconditions for an upswing. In contrast to the prosperity-phase after WWII the IT-foundation era after 1990 was not founded on widening mass consumption and participation but rather on the social differentiation of consumption. The level of commodification as well as polarization and precarization has risen sharply compared to the $1960 \mathrm{~s}$ as well as polarization and precarization. Therefore the lower strata of society suffered much stronger from marginalization than during the socially inclusive 1960s and 1970s. The criteria for in- and exclusion have changed considerably due to changed consumer and communication habits so that the squalor of poor and impoverished strata is not visible at first glance today. Therefore when there is talk about a successful upswing this does not relate to a broadening of societal participation but rather to a recovery of the foundations of capital accumulation.

Thus, the paradox of perception is repeated under reversed portents. While the recession characterising the 1970 s was interpreted as an upswing, many contemporaries viewed the upswing of the 1990s as a crisis.

\section{The Never-Ending Crisis?}

Significant objections have been raised against the theory of recovery from the world economic crisis of the 1970s, the overcoming of Fordism in the old industrial countries and the beginning of the $5^{\text {th }} \mathrm{K}$-wave based on information- and biotechnology as new leading sectors (Kuczynski 2012a: 156-161; 2012b). Similar arguments are given in Wolf 2009: 187 and Roth 2009: 146. According to these, the IT-boom during the 1990s was a short-term bubble that in no way should be interpreted as product- and processinnovation. It rather proved the point that digitalization, proposed to be a way out of the profit squeeze of Fordist mass-production, was unable to fulfil the expectation of becoming a motor for a new upswing. It did not develop a new lead sector capable of carrying expansion. In addition, financialization of the world economy only really started to develop during the 1990s and 2000s. The capital flight into the financial business so characteristic for phases of depression carried on. It can be concluded that the upswing was of a purely fictitious nature, an optical illusion retro-acting to the productive sphere due to its aggravation intensified by the crisis. No trace of recovery. The reason why the depression of the 1970s did not develop into a great crash is attributed by Thomas 
Kuczynski to a rise in demand with which the cold war stimulated the arms industry during the 1980s, while the opening of Eastern European markets after the collapse of state socialism presented western capital with a wide field of markets, takeovers as well as a tabula rasa in the field of labour and social policy. The wars against Iraq, the Taliban in Afghanistan and Pakistan the USA dragged their allies into as well as the military interventions into the civil wars in Libya, Chad and Syria can also be interpreted as factors that helped delaying the great crash due to their effect on stimulating demand within the war economy.

This interpretation of economic movement implies that there was no recovery after the world economic crisis of 1973/74. There was a never-ending depression instead. In this case, 1973 would not appear as a full blown crisis introducing a turn from A- to B-cycle but as a short-term economic decline carried over into 1980-1982, 1987, 1990/1991 and 2001 without leading to the great crash at that stage. Following this interpretation the world economy would continue remaining in the midst of the $4^{\text {th }}$ Kondratieff cycle which, after some delay, turned from its A-phase to its B-phase during the crisis of 2008 and the following years; just another type of business as usual. Everything looking like a base for a new upswing has been, when seen this way, just an element of managing and repeatedly delaying a long depression which finally began to crash in 2008 . Wallerstein's theory about the end of the capability of capitalism for renewal is compatible with this view.

The difficulty of determining the current form of the cycle in the here and now results from insufficient temporal distance and the temptation to interpret short-term phenomena on a long-term basis. But it also casts a shadow on the cyclic model as such at least where its capability for providing forecasts is concerned. When did the depression which followed the phase of recession after the world economic crisis of 1973/1974 and which introduced a new neoliberal model of accumulation based on a new international division of labour, digitalization and a widening of credit volume and financial business turn into a new recovery, a new 'Kondratieff'?

Some authors consider the recessive declines of 1980-1982, 1987, 1990/1991 and 2001 to be continuations of a long enduring downturn which found its current low-point in the world economic crisis following 2008.

In my opinion there are many reasons for regarding the neoliberal globalization of the 1990s carried by information- and biotechnology as an expression of a recovery which offered such potential for growth and renewal that 1990/1991 can be considered to be the beginning of a new cycle (the $5^{\text {th }}$ Kondratieff cycle) (see Streissler and Tichy 2012). ${ }^{4}$ It was supported by the neoliberal turn, system change in Eastern Europe and policies of opening and reform in China. The system change in the Comecon countries brought events already happening in the economic sphere since the 1973/1974 world economic crisis to a conclusion in the political sphere. These had previously been unable to fully come to fruition due to the - hollowed out - political primacy of the communist parties: the peripheral inclusion of Eastern Europe as a market, low-wage location and provider of labour for the world economy. The new cycle was based on the favourable precondition of overcoming the crisis by turning Eastern Europe into a periphery (Hofbauer 2007). This opening combined itself with the global flexibilization of trade and commodity chains which allowed some emerging countries becoming region- 
al centres for the world economy. This was most clearly expressed by the rise of China. India showed similar developments, while Brazil and South Africa did not meet those expectations. In contrast to the upswing of the 1960s and early 1970s, the A-phase of the $5^{\text {th }}$ Kondratieff cycle did not cause social integration. Rather, it caused segmentations, which did not stop at destroying social gains in the old cores. It was nevertheless associated with hope and a spirit of departure by many social groups, not least in the aspiring industrial states of Eastern and Southern Asia, Brazil and South Africa.

Eighteen years (1990/1991-2008) may seem like a very short time for a Kondratieff A-phase including recovery and prosperity. However, the upswing was able to feed from re-structuring that took place before 1991. Of course, it is also plausible that the state of the world economy does not allow for a new upswing in terms of stabilization immanent within the system, as is postulated by Samir Amin (1991) or Immanuel Wallerstein (1998). During previous crises, this necessity if not inevitability based on Marxist crisis theory provided leftists with hope time after time, that renewal on capitalist terms was completely excluded. In contrast, the long wave model can lead to viewing capitalism as a system capable of infinite renewal. It is de facto impossible to conclusively state today whether we were at the beginning of a new B-phase in 2008 which would lead to a new upswing after a phase of depression, or whether historical capitalism is in turmoil and decline as a social formation. In any case a change in the hegemonic cycle is to be expected, although there will be resistance to this.

\section{Crisis as Fracture Zone}

The long wave model can be useful, even when we do not view crises in a deterministic way but as open-ended moments in which different forces in society advocate their strategies for solutions and societal models. It would make sense in this respect not to concentrate on the phase of prosperity in which the hegemony of unipolar rule only gives limited room for manoeuvre, but to take the crisis as a starting point for analysis.

At the turning point in historical development the following options can be played out:

-Which paths for overcoming the crisis do arise from within the system?

- Which anti-systemic forces do articulate themselves in the moment of crisis via public criticism and social protest, and do they formulate demands and programmes towards more social justice?

- Which counter-forces do form to counter the anti-systemic forces for stabilizing the system in times of danger on the one hand and on the other hand to use instability for the implementation of authoritarian solutions?

- Another response to anti-systemic critique is achieved by re-directing criticism into reform, not leading to the overcoming but rather the renewal of the system to become the favoured option. Variant 4) thus fits into variant 1).

Table 3 illustrates these four variants with regard to the world economic crises of $1873,1929,1973 / 1974$ and 2008. Restrictively one should add that this presentation uses the perspective of western industrial countries and of the hegemonic and counterhegemonic forces and active social movements in those countries. 
Table 3

Crisis as fracture point for systemic, anti-systemic and anti-anti-systemic movements

\begin{tabular}{|l|l|l|l|l|}
\hline \multicolumn{1}{|c|}{ Crisis } & \multicolumn{1}{|c|}{$\begin{array}{c}\text { Way out within } \\
\text { the system }\end{array}$} & $\begin{array}{l}\text { Anti-systemic } \\
\text { force }\end{array}$ & $\begin{array}{c}\text { Anti-anti- } \\
\text { systemic force }\end{array}$ & $\begin{array}{c}\text { Criticism of the system }> \\
\text { reform }\end{array}$ \\
\hline $\begin{array}{l}\text { Years following } \\
1873\end{array}$ & Classic imperialism & Socialists & Nationalists & $\begin{array}{l}\text { Parliamentary and elec- } \\
\text { toral reform }\end{array}$ \\
\hline $\begin{array}{l}\text { Years following } \\
1929\end{array}$ & $\begin{array}{l}\text { Stimulus programmes, } \\
\text { war }\end{array}$ & Leftists & Fascists & - \\
\hline $\begin{array}{l}\text { Years following } \\
1973\end{array}$ & $\begin{array}{l}\text { New international } \\
\text { division of labour } \\
\text { global commodity } \\
\text { chains, digitalization }\end{array}$ & $\begin{array}{l}\text { New social } \\
\text { movements }\end{array}$ & - & $\begin{array}{l}\text { Co-optation of anti- } \\
\text { systemic forces and } \\
\text { their criticism into the } \\
\text { system }\end{array}$ \\
\hline $\begin{array}{l}\text { Years following } \\
2008\end{array}$ & $\begin{array}{l}\text { Global governance in } \\
\text { the name of free trade } \\
\text { instead of democratic } \\
\text { participation }\end{array}$ & $\begin{array}{l}\text { Various } \\
\text { uprisings }\end{array}$ & New Right & Consumerist promise \\
\hline
\end{tabular}

\section{Crisis and Hegemonic Change}

When taking up the suggestion made by world-system analysis to combine economic cycles with hegemonic cycles there arise some questions often debated in the media: Against the background of China's rise as a global player, is there a turn from U.S. hegemony towards a new hegemon within the world system? Can a state, an alliance of states or a world region qualify as such and how this hegemonic change will occur? Can an analysis of previous tendencies be useful for a debate about questions about the future? Or does the continuation of old patterns prevent possibilities for creative solutions? The following considerations should therefore not be read as a forecast but rather as thought-games designed to help systematize and objectify the options on the basis of previous developments and ruptures.

The exhaustion of the American hegemonic cycle seems uncontested. The United States' decline was initiated by the revocation of the Bretton Woods system and the world economic crisis of 1973/1974. Since then we were able to observe how a declining hegemonic power behaves. It protects old privileges, activates old alliances (NorthAtlantic, Pacific) and forms new alliances such as the tacit agreement with China, whose export-surplus finances the US budget and current account deficit which means the US dollar can continue to act as reserve currency. Another symptom for declining power is military interventions to secure raw materials and regional interests and to use war to revive the economy.

At the same time the applicants for the replacement of the old hegemon move into position. The loudest voice formulating such claims comes from the European Union, which re-affirmed its aim to play a more substantial role as a 'global player' in the Lisbon treaty of 2007/2009. Other potential followers are China, eventually together with other larger emerging nations who are underlining the growing strength of the global south by participating at summits like the G20 as well as by developing South-South cooperation (e.g., in the framework of BRICS). 
An indispensable precondition for assuming a global leadership role is an economic base with a diversified economic structure and innovative, profitable companies allowing dominating lead sectors of growth, lead innovations and global value chains in the interest of local capital groups. A global hegemon has to be a core of the world economy at the same time. Each applicant will aim to develop regional integration in order to build cross-regional competitiveness based on an expanding single market. We can observe such developments with the European Union, NAFTA and ASEAN.

At present we can also observe the attempts to build trading blocks that reach beyond existing regional integration projects, like the Transpacific Partnership Agreement (TPA) or the Transatlantic Trade and Investment Partnership (TTIP), both under the leadership of the United States. They are aiming at preventing China from increasing its global influence. They do face strong resistance from various sides, however. On the other hand, there are several regional cooperation and free trade zones in Africa, Latin America and on the territory of the former USSR. Which of these can successfully establish itself as a core of the world economy or even rise to becoming a hegemon?

The decline of the US hegemony was paralleled by the formation of the European Union as a supranational block. The advantage of a great and steadily expanding single market is based on the convergence of economic freedoms of capital, goods, services and labour, whilst the divergence in social, regional and tax policy enabled companies who are active across borders to capitalize on differences in wage, tax, and social welfare levels. The project which, in the form of the euro, brought about a candidate for the succession of the US dollar seems to currently be about to break up due to its immanent dynamics. Social and regional cohesion is put in danger by a growing polarization into centres and peripheries. The continued existence of the euro is put into question although massive amounts of government spending were used to stabilize banks and creditors. A larger integrated area involving Russia and other USSR successor states which could have lent more weight to Europe as a successor of the USA was only rudimentarily realized in projects such as the North Stream gas pipeline. It was strongly opposed from the new eastern European EU members who strengthened NATO. The failure of building a union with Russia has not only been rooted in a lack of will among the European Union but also in the dominance of US interests in maintaining global military leadership in a period of domestic and global economic and social decline. Therefore the US is obliging European NATO allies to confirm and support their leading role. This made cooperation with Russia on an equal level impossible. But it was also due to the implosion of Russian state power, which in the course of privatizing state assets transformed into an oligarchy, which put objectives of national economy on the back burner. Russia struggles to stabilize its economy and keep afloat as a regional power without being able to play a role in our thoughts about hegemonic succession. However, Russia deserves attention as a possible partner for Chinese projects to increase regional cooperation in Northeast Asia as well as along the so-called New Silk Road.

There are some indications that China, which evolved from being a developing nation in 1978 to becoming the largest, at first - and in many ways for the foreseeable future - 'extended' workshop of the world since the beginning of the A-phase during the 1990s, could work itself up to becoming an economic core (see Komlosy 2011a: 73104; 2012b: 45-59). And that China was able to develop its own strategy for growth 
and innovation in the face of the peripheralization pressure emanating from its integration as a cheap labour location at the labour intensive end of the global commodity chain was due to its size, its huge, ready and disciplined population full of hope for and motivated by a possibility of social advancement as well as the regulating hand of stateand party-leadership. While costs for investors were kept low, protests were repressed and workers' hopes put off to the future, political specifications ensured that profits from industrial foundations and contract production did not only favour foreign investors but also strengthened the capital base and know-how of companies as well as the qualifications of workers. Domestic consumption by the broad masses was shelved in favour of national economic capital accumulation, which could be regarded as a strategic effort to develop global hegemony. By providing a good service in stabilizing the debt ridden USA China positioned itself as a power already playing a role in the global struggle for hegemony although it does not fulfil any of the economic, political and social preconditions necessary for this. Since the middle of the first decade and even more so since the beginning of the economic crisis during the years following 2008 which made visible the fragility of export earnings, the Chinese government set course on an economic policy designed to strengthen value adding intensive sectors and science, to develop control functions within global commodity chains and to strengthen domestic demand. This is combined with improving social rights of workers and including wide spread undeveloped parts of central China into the industrialization programme. Thus, China carries out an integration process within its borders, which shows some parallels with EU integration. It activates the potential of a greater area characterized by huge differences in levels of development. Extended workshops are being transferred into the central areas while coastal areas are becoming concentrated global centres with company headquarters, research and development sites, high-ranking services and strong purchasing power. There is a risk that social polarization inherent in this process can increase social tensions - including the potential for ethnicization - which could be a precursor for a crisis of the state. On the other hand, material living conditions of most people are on a much lower level and it is most likely that people are willing to suffer hardships for social advancement. Another resort to better the Chinese position within the international division of labour is provided by surrounding developing nations who gladly take up the supply orders for 'global buyers' which disproportionally went to China especially after the Multi Fibre Arrangement ran out in 2004 (Komlosy 2011a: 83). When China is moving up the commodity chain by taking over high end and logistic control, it is on the way to take up the position of a regional centre. China has been involved in regional integration with neighbouring countries for a few years now. The acquisition of companies in strategically vital industry and worldwide infrastructure sites, the securing of spheres of influence, the buying of agricultural fields to compensate for a lack of food resource capacities in Africa provide proof for the intent to become a global world economic centre. The current transitional phase hardly allows for separating economic ambitions from geopolitical ones. Should China succeed in consolidating itself as an economic centre, which could grow into the role of a hegemonic power in the long term, the continuation of historical capitalism would be guaranteed. As predicted by André Gunder Frank and others, the epicentre of global lead processes would shift to East Asia, which could once more take up the leading role 
played by this region from the fourteenth until the eighteenth century (Frank 1998). Continuity does not at all have to mean more of the same but could go along with an adaptation to Asian values and attitudes, which could develop pressure and serve as an example to follow and a lead culture for other world regions. The combination of capitalism with political democracy as was characteristic for the cores of the world economy during the time of British and US-American hegemony could change towards a more authoritarian capitalism, which does not rely on democratic elections but on 'social harmony'. The fact that this combination would look different within the - Asian core than in regions who would have these values forced upon them by virtue of being peripheries or semi-peripheries would not make a fundamental difference to the method of cores having the power to determine the discourse as has been practised so far.

It is not at all certain that this scenario will come into fruition. Previous experiences would suggest that the path towards this goal will move through further Kondratieff cycles allowing the rising hegemon to develop its specific leadership qualities. Hegemonic maturity would probably only be achieved by the middle of the twenty-first century. It cannot be excluded that the road to that point would be plastered with regional and maybe even globally escalating wars. These can be defensive and assertive battles waged by the old hegemonic power and its allies. The worsening regional conflicts in the Pacific, where the USA - still the dominant military power - has recently begun concentrating its military potential confirm this. At the same time military clashes with neighbours trying to prevent a Chinese hegemon as well as competing applicants for hegemony have to be deemed possible. The peaceful US-Chinese symbiosis in which China supported the old hegemon by buying US government bonds cannot be kept up under these conditions. The Chinese programme to strengthen its domestic market as well as stated US government aims of re-industrialization point towards the end of the cooperation which has carried the $5^{\text {th }}$ Kondratieff A-phase.

It may happen that there will not be any new hegemons. From an optimistic view this could mean a multipolar, peaceful equilibrium. When interpreted pessimistically, this may mean permanent instability and threat of war. If there is no cyclical renewal of capital accumulation in a crisis just getting endlessly worse this could be connected to an end of historical capitalism as predicted by Immanuel Wallerstein. He calls on social movements to shape this upheaval in the spirit of social justice, so that it can be as peaceful as possible, on equal terms and as egalitarian as possible.

\section{The article was translated from German by Christian Bunke}

\section{NOTES}

${ }^{1}$ For a comparison of these crises see Karl Heinz Roth (2009: 285ff.); Winfried Wolf (2009: 182-185).

${ }^{2}$ In the early years of world-system research most scholars agreed with the following time and space model, most prominently developed by Wallerstein (2011a) and Arrighi (1994). In the meanwhile the scope of timing and periodizing systemic interactions has remarkably broadened, giving way to controversial debates. For a summary see Komlosy 2011b: 195-209.

${ }^{3}$ Long wave approaches were taken up by various scholars and world-system research groups. A major stimulus to adopt a cyclical perspective was marked by the global crisis of 1973/74, as reflected by Amin et al. (1982). Long wave models differed according to the conceptualization of the world system as a single or a multiple one, a global or a European one, with different assumptions 
about its beginning, periodization, geographical reach, hegemons, perspectives, and possible ends. Amin et al. (1982) proposed a concept of system that started with European expansion in the sixteenth century, step by step incorporating the rest of the world (see Overview 1). Later Frank developed a global frame-work that encompassed the globe into a single world-system from the Neolithic revolution onwards, locating its most developed region in eastern Asia until the early nineteenth century (see Frank 1998). Arrighi observed a sinocentric world-system coexisting with the capitalist one that became hegemonic in the nineteenth century (Arrighi 2007). Equally, Modelski and Thompson do not confine Kondratieff cycles to the modern period of factory-industry but trace them back into Song China and Renaissance Italy (see Modelski and Thompson 1996). In Russia cycle theories have their own history. More recently, long cycles have been rediscovered by a group of Russian scholars around the Kondratieff Waves Yearbook that offers a forum for international debate. They integrate the findings of the mostly Angloamerican world-system scholars with other traditions of cycle theory, placing long waves in the centre of a historically grounded discussion about the future trajectories of humankind (see Grinin, Devezas, and Korotayev 2012, 2014; Grinin, Korotayev, and Tausch 2016).

${ }^{4}$ Kondratieff Waves Yearbooks mirror the vivid debate about the existence and the timing of the 5th and 6th Kondratieff cycle.

\section{REFERENCES}

Amin, S. 1991. L'Empire du chaos. La nouvelle mondialisation capitaliste. Paris: L'Harmattan.

Amin, S., Arrighi, G., Frank, A. G., and Wallerstein, I. 1982. Dynamics of Global Crisis. New York - London: Monthly Review Press.

Arrighi, G. 1994. The Long $20^{\text {th }}$ Century. Money, Power, and the Origins of Our Time. London - New York.

Bornschier, V., and Lengyel, P. 1992. Waves, Formations and Values in the World System. New Brunswick, N. J.: Transaction Publishers.

Frank, A. G. 1998. Re-Orient. Global Economy in the Asian Age. Berkeley - London: University of California Press.

Fröbel, V., Heinrichs, J., and Kreye, O. 1977. Die neue internationale Arbeitsteilung. Reinbek bei Hamburg: Rowohlt.

Galbraith, J. K. 2009. Der große Crash 1929. Ursachen, Verlauf, Folgen. München.

Gereffi, G. 1994. The Organization of Buyer Driven Commodity Chains: How US Retailers Shape Overseas Production Networks. Commodity Chains in Global Capitalism / Ed. by G. Gereffi, and M. Korzeniewicz. Westport, CT.

Grinin, L. E., Devezas, T. C., and Korotayev, A. V. (Eds.) 2012. Kondratieff Waves: Dimensions and Perspectives at the Dawn of the $21^{\text {st }}$ Century. Volgograd: 'Uchitel' Publishing House.

Grinin, L. E., Devezas, T. C., and Korotayev, A. V. (Eds.) 2014. Kondratieff Waves. Yearbook. Volgograd: Uchitel Publishing House.

Grinin, L., Korotayev, A., and Tausch, A. 2016. Economic Cycles, Crises, and the Global Periphery. Heidelberg - New York - Dordrecht - London: Springer International Publishing.

Hofbauer, H. 2007. EU-Osterweiterung. Historische Basis - ökonomische Triebkräfte soziale Folgen. Wien: Promedia.

Roth, K.-H. 2009. Die globale Krise. Hamburg: VSA Verlag. 
Komlosy, A. 2011a. Vom Nachzügler zum Trendsetter. Chinesische Arbeitswelten im Textil- und Bekleidungssektor. Blätter für Technikgeschichte 73: 73-104.

Komlosy, A. 2011b. Globalgeschichte. Methoden und Theorien. Wien - Köln-Weimar: Böhlau.

Komlosy, A. 2012a. Nachholende wirtschaftliche Entwicklung. Konzepte, Beispiele und Kriterien für Erfolg oder Scheitern. Zeitschrift für Weltgeschichte 13 (2): 11-42.

Komlosy, A. 2012b. Zyklische Erneuerung oder Endkrise des historischen Kapitalismus. Z. Zeitschrift Marxistische Erneuerung 89: 45-59.

Kondratieff, N. 1993 [1925]. Long Cycles of Economic Conjuncture. Selected Works / Ed. by L. K. Abalkin, pp. 24-83. Moscow: Ekonomika.

Kuczynski, T. 2012a. Ausweglose Lagen gibt es nicht. Steht das Kapital vor einem neuen Mehrwertschub? No way out? / Ed. by H. L. Gremliza, pp. 156-161. Hamburg.

Kuczynski, T. 2012b. Krisenverschiebungen. Wiseo das Krisenbündel 2007ff bloß die Krise von 1973ff fortsetzt. Lunapark21. Zeitschrift zur Kritik der politischen Ökonomie 19: $68-69$.

Mandel, E. 1980. Long Waves of Capitalist Development. Cambridge: Cambridge University Press.

Modelski, G., and Thompson, W. R. 1996. Leading Sectors and World Powers. The Coevolution of Global Politics and Economics. Columbia: University of South Carolina Press.

Roth, K. H. 2009. Die globale Krise. Hamburg.

Schumpeter, J. A. 1939. Business Cycles. A Theoretical, Historical and Statistical Analysis of the Capitalist Process. 2 vols. New York - Toronto - London: Mc Graw-Hill Book Co.

Streissler, E., and Tichy, G. (Eds.) 2012. How to Forecast Economic Developments During and after Crises. Wien.

Taylor, P. 1996. The Way the Modern World Works. World Hegemony to World Impasse. Chichester.

Wallerstein, I. 1983. Historical Capitalism. London: Verso.

Wallerstein, I. 1998. Utopistics, or Historical Choices of the $21^{\text {st }}$ Century. New York: The New Press.

Wallerstein, I. 2001. The Modern World-System. 4 vols.

Wallerstein, I. 2011a. The Modern World-System. Vols. I-IV. $2^{\text {nd }}$ edition with new prologues. Berkeley - Los Angeles - London: University of California Press.

Wallerstein, I. 2011b. The Modern World-System IV - Centrist Liberalism Triumphant, 1789-1914. Berkeley: University of California Press.

Wallerstein, I. 2013. Structural Crisis, or Why Capitalists Can no Longer Find Capitalism Rewarding. Does Capitalism have a Future? / Ed. by I. Wallerstein, R. Collins, M. Mann, G. Derluguian, and C. Calhoun, pp. 9-36. Oxford: Oxford University Press.

Wolf, W. 2009. Sieben Krisen - ein Crash. Wien: Promedia. 